\title{
Bird-plant interaction networks in native forests and eucalyptus plantations within a protected area
}

\author{
Cristian Daniel Veliz Baldiviezo ${ }^{1,2}$; Marcela Fortes de Oliveira Passos ${ }^{1,3}$ \& Cristiano Schetini de Azevedo ${ }^{1,4}$ \\ 1 Universidade Federal de Ouro Preto (UFOP), Instituto de Ciências Exatas e Biológicas (ICEB), \\ Departamento de Biodiversidade, Evolução e Meio Ambiente (DEBIO), Laboratório de Zoologia dos Vertebrados. Ouro Preto, MG, Brasil. \\ 2 ORCID: http://orcid.org/0000-0001-5883-097X. E-mail: cristian_v_b_y@hotmail.com \\ 3 ORCID: http://orcid.org/0000-0002-0992-5515. E-mail: marcelabiol@hotmail.com \\ ${ }^{4}$ ORCID: http://orcid.org/0000-0003-0256-9017. E-mail: cristianoroxette@yahoo.com (corresponding author)
}

\begin{abstract}
Frugivory is a plant-animal mutualistic interaction carried out mostly by birds. It consists in the bird consumption of fruits with later dispersion of the plants' seeds, helping in the vegetation regeneration. Frugivory can be affected by the habitat fragmentation and introduction of exotic species, which may alter the species interaction by extinction or competitor introduction. This study aimed to compare the structure of the network of frugivorous interactions between birds and plants in native forest and eucalyptus plantation. Birds were captured by mist nets and had their feces collected. Later, the seeds were identified in laboratory. The records of fruit consumption by birds in the zoochoric plant species present in the study area were also conducted. The data collected was used to build a network of interactions and identify the most important network metrics, species, and ecological functional groups in the studied environments. The results showed that the species composition, the connectivity of the relationships, the importance of the species for the interaction networks and the number of subgroups within the networks were highly similar between the native forest and the eucalyptus plantation. This could be explained by the favorable conditions that the studied eucalyptus plantations presented, such as the lack of anthropogenic activities, well-developed understory, and the presence of native surrounding vegetation, allowing practically the same seed dispersal capacity in both types of environments.
\end{abstract}

Keywords. Bird-plant interactions; Exotic species; Frugivory; Zoochory.

\section{INTRODUCTION}

Ecosystems with extensive plantations of non-native trees, such as the eucalyptus monocultures, can extinguish local species by replacing native vegetation and simplifying the forest heterogeneity, alter the regional water resources, and diminish soil fertility (Marsden et al., 2001; Borsboom et al., 2002; Kanowski et al., 2005; Carnus et al., 2006; Valduga et al., 2016; Bayle, 2019). On the other hand, eucalyptus plantations can be used as fuelwood, replacing the use of indigenous species, and conserving native forests and wildlife, protecting soil from erosion, and help in habitat restoration by promoting the recruitment, establishment and succession of native woody species (Hobbs et al., 2003; Barlow et al., 2007; Brockerhoff et al., 2008; Bremer \& Farley, 2010; Brockerhoff et al., 2013; Bayle, 2019). All these negative and positive effects have been much debated on whether they prevent forest regeneration (Altieri, 2009; Edwards et al., 2014;
Benton et al., 2021). However, little is known about the consequences of eucalyptus plantations for seed dispersal.

Seed dispersal is considered the most important ecological process for the natural regeneration of vegetation (Bascompte \& Jordano, 2007), occurring in most cases through frugivory (fruit consumption). Frugivory allow mutualistic animal-plant interactions in which more than two species are usually involved, that may form a complex network of interactions, capable of maintaining the resilience, and even the regeneration, of the ecosystem through the spread of propagules (Bascompte \& Jordano, 2007). Mutualistic animal-plant interactions are influenced by environmental disturbances, such as habitat fragmentation and introduction of exotic species, by the exclusion or introduction of key species in the system, preventing pre-existing relationships in the interaction network (Markl et al., 2012). To understand how a species becomes a key player in a network of mutualistic interactions, we need to 
assess the importance of the species in a complex context and through quantitative operational metrics (Mello et al., 2015).

In South America, specifically in Brazil, eucalyptus is the most widespread exotic monoculture, which places the country as the second in the world with the largest area of native forest replaced by plantations of this tree (Ceccon, 2001). This fact led to changes in many ecosystems, such as the Atlantic Forest, considered one of the most fragmented domains in the Neotropics (Ceccon, 2001; FAO, 2016). This is the domain with the largest number of endemic species in Brazil (it is considered a biodiversity hotspot; Myers et al., 2000; Rezende et al., 2018). Because of this problem, some areas of the Atlantic Forest were converted into protected areas, such as the Itacolomi State Park (PEIT), located in southeastern Brazil, which include both native vegetation and a 30-year abandoned eucalyptus plantation. The PEIT is considered an important historical and geological natural park in the region (Tafuri, 2008; Messias et al., 2017). Studies, such as those of Andrade (1998), Governo do Estado de Minas Gerais et al. (2007) and Pereira et al. (2015), highlighted the high bird diversity of the PEIT, indicating the probability of existence of a complex birdplant interaction networks.

Birds play a fundamental role in the establishment and evolution of native vegetation, with many species that consume and potentially disperse seeds, hence contributing to the forest restoration in degraded areas (Fleming \& Kress, 2011). In addition, birds have the largest number of frugivorous species in the Neotropics, with some families being dependent or highly dependent on eating fruits (Fadini \& De Marco, 2004; Hernández-Ladrón de Guevara et al., 2012). For these reasons, it would be important to evaluate the contribution of birds to seed dispersal inside the PEIT, evaluating if the replacement of native vegetation by eucalyptus plantations interfere with birds-plant interaction network. This study aimed to compare the relationships between frugivorous birds and zoochoric plants in the forests of the PEIT, by comparing bird-plant interaction networks in an area of native forest with an area of eucalyptus plantation. We hypothesized that the richness of seed dispersing birds would be lower in the eucalyptus plantation than in native forest areas due to the replacement of native vegetation by the monoculture. Also, we hypothesized that the interaction network would be more connected in the native forest than in the eucalyptus plantation, due to the exclusion of frugivorous birds and their mutualistic native plant species by the eucalyptus trees (Valduga et al., 2016).

\section{MATERIAL AND METHODS}

\section{Study Area}

The study was carried out at the Itacolomi State Park (PEIT), a protected area located in the southeast of the state of Minas Gerais, between the municipalities of Ouro
Preto and Mariana ( $\left.43^{\circ} 32^{\prime} 30^{\prime \prime} \mathrm{W}, 20^{\circ} 22^{\prime} 30^{\prime \prime} \mathrm{S}\right)$. The PEIT has an area of 7,543 ha, with altitudes varying between 700 to 1,772 m.a.s.l. The region's climate, according to the Koeppen classification, is dry-winter subtropical highland climate $(\mathrm{CWb})$, as temperatures can vary from 4 to $33^{\circ} \mathrm{C}$, with an annual average of $20^{\circ} \mathrm{C}$. Precipitation is concentrated between the months of October and March, with a notorious wet season during summer and another dry season in winter (Tafuri, 2008). In the PEIT, rupestrian grasslands occupy $51 \%$ of its territory $(3,846.93 \mathrm{ha})$, $40 \%$ is covered by montane Atlantic Forest (3,017.2 ha), and $9 \%$ is occupied by a 30 -years abandoned eucalyptus plantation (two blocks totaling $678.87 \mathrm{ha}$ ), placed in an area previously occupied by the native Atlantic Forest, as long as abandoned tea plantations and human constructions (Messias et al., 2017). In this protected area, have being recorded 1,623 plant species, 251 birds, 43 mammal species, 37 amphibians and 22 reptiles, showing its high biodiversity (Governo do Estado de Minas Gerais et al., 2007; Messias et al., 2017).

The study was conducted in two different habitats: native Atlantic forests and abandoned eucalyptus plantations. In each habitat, three sample units were set. In each sampling unit, six $30 \mathrm{~m}^{2}$ transects were placed, equidistant $200 \mathrm{~m}$ (Cullen et al., 2006), for data collection. The native forest sample units were located in $1\left(20^{\circ} 25^{\prime} 44.3^{\prime \prime} \mathrm{S}, 43^{\circ} 30^{\prime} 50.4^{\prime \prime} \mathrm{W}\right)$ and $3\left(20^{\circ} 25^{\prime} 37.9^{\prime \prime} \mathrm{S}\right.$, $\left.43^{\circ} 30^{\prime} 36.7^{\prime \prime} \mathrm{W}\right)$ were set in an Atlantic Forest fragment comprising $0.65 \mathrm{~km}^{2}$, while the native forest sample unit $2\left(20^{\circ} 25^{\prime} 33^{\prime \prime} \mathrm{S}, 43^{\circ} 30^{\prime} 22^{\prime \prime} \mathrm{W}\right)$ was set in an Atlantic Forest fragment of $0.21 \mathrm{~km}^{2}$. The Atlantic Forest fragments were $800 \mathrm{~m}$ distant from each other. The eucalyptus plantation sample units $1\left(20^{\circ} 26^{\prime} 06.6^{\prime \prime} \mathrm{S}, 43^{\circ} 30^{\prime} 14.2^{\prime \prime} \mathrm{W}\right)$ and 2 $\left(20^{\circ} 26^{\prime} 16.9^{\prime \prime} \mathrm{S}, 43^{\circ} 31^{\prime} 14.6^{\prime \prime} \mathrm{W}\right)$ were set in an abandoned eucalyptus plantation fragment comprising $1.62 \mathrm{~km}^{2}$, while the sample unit $3\left(20^{\circ} 26^{\prime} 17.4^{\prime \prime} \mathrm{S}, 43^{\circ} 31^{\prime} 07.2^{\prime \prime} \mathrm{W}\right)$ was set in an abandoned eucalyptus plantation of $0.4 \mathrm{~km}^{2}$. Both eucalyptus plantations were $1 \mathrm{~km}$ distant from each other. The sampled units of the abandoned eucalyptus plantations were distant at least $1 \mathrm{~km}$ from the sampled units of the native vegetation.

Eucalyptus grandis W. Hill ex Maiden formed the abandoned eucalyptus plantations, with trees reaching heights up to $45 \mathrm{~m}$. A developed understory, formed by native plant species with up to $15 \mathrm{~m}$ height, could be observed in the abandoned eucalyptus plantation. Common native plant species such as Schinus terebinthifolius Raddi and Drimys brasiliensis Miers are found in native forest. A dense understory, with plants measuring from 15 to $18 \mathrm{~m}$ is present in the native vegetation area.

\section{Fecal Samples}

Sets of 10 mist nets ( $35 \mathrm{~mm}$ mesh, $12 \mathrm{~m}$ length $\mathrm{x}$ and $2.5 \mathrm{~m}$ width) were installed in the three sampling units of both the native forest and the eucalyptus plantation. The nets remained open for sampling between 06:00 $\mathrm{h}$ until 12:00 h, totaling 180 hours in each habitat, for 10-month samplings. Each net was inspected at 30 min intervals 
during the sampling period. Once a bird was captured, the species was identified using a field guide (Sigrist, 2014). Then, each captured bird was placed in a cloth bag with filter paper for 15 or 30 minutes until it defecated, and the feces were preserved in $70 \%$ alcohol for later laboratory analysis (León, 2010; Hernández-Ladrón de Guevara et al., 2012).

All fecal samples were placed in petri dishes and diluted with $70 \%$ alcohol to separate intact seeds using a stereoscopic microscope in the laboratory. The seed identification in feces was carried out using seed identification guides (Kuhlmann, 2012; Frigieri et al., 2016) and by comparison with collections of fruits and seeds of exsiccates present at the Herbário Professor Jose Badini of the Federal University of Ouro Preto (OUPR). Interaction data were collected from each fecal sample, and an interaction record was considered valid whenever a fecal sample of a bird species contained intact seeds (seeds not broken during gut passage) from a given plant species. The number of seeds within fecal samples was not recorded due to the difficulties that would lead to an underestimation of some species with very tiny and numerous seeds, such as those of the Melastomataceae family.

\section{Visual Recordings}

Focal observations of the plants whose fruits were consumed by frugivorous birds were conducted in the six transects of each sampling areas, from $06: 00 \mathrm{~h}$ to 11:00 h and from 15:00 h to 18:00 h (Pizo \& Galetti, 2010), for 10 months, totaling 240 hours of observation in each type of habitat. The number of bird-plant interactions per species was recorded, considering an interaction when a bird species consumed fruits of a plant species, in a way that every plant species may have numerous/ many interactions when fruits were consumed by several bird species, and a bird species could have multiple interactions when consuming fruits of several plant species (Silva et al., 2002; Pizo \& Galetti, 2010; Cullen et al., 2004). In each transect, the plant species with fleshy fruits were sampled, and the fruits were placed in alcohol $70 \%$ and taken to the laboratory for later identification (Caziani, 1996; Amico \& Aizen, 2005).

\section{Data Analysis}

An interaction network is the graphic representation of a complex system of multiple potentially connected elements, in which the connection may be a mutualistic relationship, and the elements are the plants and birds (Bascompte \& Jordano, 2014). To identify the importance of species and groups of species in the interaction network in the sampled habitats, the following network metrics were calculated following Mello et al. (2015), Costa et al. (2016) and Mello et al. (2016). The degree of connection or connectivity, which is used to compare the pair of species that interact the most within the network, thus showing the strongest bird-plant relationships in the community. The degree of centrality, which points out the species with greater number of interactions. The centrality by proximity or closeness centrality, that estimates which species are more likely to interact with others within the network, in other words, showing the species with the greatest indirect relationship with other species in the network. The centrality by intermediate or betweenness centrality, which indicates the species that are mediating the interaction between two other species within the community. Finally, the Louvain modularity (Q) was used to assess if the relationships are equally distributed between birds and plants or if they are separated into subgroups (modules) within the community.

All metrics were calculated using the software Pajek 4.09 (Batagelj \& Mrvar, 1998) and non-parametrical Mann-Whitney tests were used to compare the resulting metrics between the two types of sampled habitats using the software R 3.5.0. (R Development Team, 2018). Complementarily, the Sorensen Index for similarity between communities, the Index of dispersion importance, and the Index of importance for plants were calculated for each habitat. The Sorensen Index for similarity between communities (IS) indicates the similarity in the species composition of the compared communities was calculated using the formula IS $=2 \mathrm{c} / \mathrm{a}+\mathrm{b}-\mathrm{c}$, where " $c$ " represents the number of species recorded in both environments, "a" the number of species in the first environment (native forest), and " $b$ " the number of species in the second environment (eucalyptus plantation) (Rabinovich, 1981). The Dispersion Importance Index (DII) indicates the importance of each bird species as a seed-disperser in the studied habitats and it was calculated using the formula DII $=(S * B) / 1000)$, where $S$ represents the relative abundance of each captured species, and $B$ represents the percentage of fecal samples with seeds of each species; DII values ranges from 0 to 10 , where 0 represents no seeds found on the feces and 10 represents a unique bird species dispersing all seeds (Galindo et al., 2000). Finally, the Index of importance for plants (IVIP), which represents the importance of a bird species for seed dispersal of a given plant, was calculated using the formula IVIP $=\Sigma(r / R)$, where $r$ represents the number of times a bird species presented seeds of a plant species in its feces and $R$ represents the total number of plant species consumed by a bird species (Galindo et al., 2000; León, 2010). Then, after testing data normality using the Lilliefors test, we used paired t-tests to evaluate if the total richness of seed dispersing birds were higher in the native forests than in the eucalyptus forests.

\section{RESULTS}

A total of 419 individuals from 21 bird species were captured with mist nets, from which 318 samples of feces were obtained. The intact seeds found in the feces belong to 17 species of plants (one seed type was identified to genus, two to family, and three remained as morphospecies). In the native forest area, 42 species of birds were recorded, with 17 captured by the mist nets and 35 regis- 
tered through focal observations. On the other hand, 36 species of birds were recorded in the eucalyptus plantation, with 13 captured by the mist nets and 30 registered by the focal method (Table 1). In both native forest and eucalyptus plantation, the most common plant genus found in bird droppings was Miconia (Melastomataceae), followed by Leandra (Melastomataceae) and Myrsine (Primulaceae), the first two are undergrowth shrubs in the studied area, and the third being arboreal. No differ- ences in seed dispersing by birds were found between native forests and eucalyptus plantations $(t=1.20$, $p=0.25$ ).

Within the native forest fragments, 50 interactions between 17 bird species and 20 plant species were recorded through fecal analysis (Fig. 1A); while, in the eucalyptus plantation fragments 41 interactions, between 13 species of birds and 19 species of plants were recorded (Fig. 1B). On the other hand, with focal observation sam-

Table 1. Bird and plant species recorded in the two types of sampled habitats of the Itacolomi State Park (PEIT) with each used methodology: cap = Bird captured in mist nets, $\mathrm{fe}=$ plant recorded in fecal samples, obs $=$ species recorded by focal observation.

\begin{tabular}{|c|c|c|c|c|c|}
\hline Bird Species & Native & Eucalyptus & Plant Species & Native & Eucalyptus \\
\hline Basileuterus culicivorus & cap & obs & Aegiphila integrifolia & fe/obs & obs \\
\hline Chiroxiphia caudata & cap/obs & cap/obs & Cupania vernalis & obs & \\
\hline Coereba flaveola & obs & obs & Fuchsia regia & fe/obs & fe/obs \\
\hline Conopophaga lineata & & cap & Leandra australis & $\mathrm{fe}$ & fe \\
\hline Dacnis cayana & obs & & Leandra glabrata & $\mathrm{fe}$ & $\mathrm{fe}$ \\
\hline Elaenia flavogaster & & obs & Leandra melastomoides & $\mathrm{fe}$ & fe \\
\hline Elaenia mesoleuca & obs & obs & Myrcia excoriata & obs & \\
\hline Elaenia obscura & cap/obs & cap/obs & Miconia chamissois & fe & fe \\
\hline Elaenia sp. & obs & obs & Miconia flammea & & obs \\
\hline Euphonia chlorotica & & obs & Miconia corallina & $\mathrm{fe}$ & obs \\
\hline Hemithraupis ruficapilla & obs & & Miconia elegans & fe & fe \\
\hline Hylophilus poicilotis & obs & & Miconia paniculata & fe & \\
\hline Ilicura militaris & cap/obs & cap/obs & Miconia rimalis & fe/obs & fe/obs \\
\hline Knipolegus cyanirostris & obs & obs & Miconia theaezans & fe/obs & fe/obs \\
\hline Manacus manacus & cap/obs & cap & Miconia valtheri & & fe/obs \\
\hline Mionectes rufiventris & cap/obs & cap/obs & Morphospecies 1 & fe & $\mathrm{fe}$ \\
\hline Myiarchus ferox & obs & & Morphospecies 2 & fe & fe \\
\hline Myiophobus fasciatus & & obs & Morphospecies 3 & fe & $\mathrm{fe}$ \\
\hline Myiothlypis leucoblephara & cap & & Myrcia splendens & obs & \\
\hline Myiozetetes similis & obs & obs & Myrcia vauthiereana & obs & obs \\
\hline Neopelma chrysolophum & cap & cap & Myrsine coriacea & $\mathrm{fe}$ & $\mathrm{fe}$ \\
\hline Pachyramphus viridis & obs & obs & Myrsine umbellata & fe/obs & fe/obs \\
\hline Penelope obscura & cap/obs & & Phoradendron undulatum & fe & fe \\
\hline Phaeomyias murina & & obs & Pipersp. & & $\mathrm{fe}$ \\
\hline Phibalura flavirostris & obs & & Poaceae 1 & & $\mathrm{fe}$ \\
\hline Phyllomyias fasciatus & & cap/obs & Poaceae 2 & fe & fe \\
\hline Piranga flava & obs & & Rudgea sessilis & obs & obs \\
\hline Pyriglena leucoptera & cap & & Schinus terebinthifolius & fe/obs & obs \\
\hline Saltator similis & obs & obs & Struthanthus concinnus & fe/obs & fe/obs \\
\hline Schiffornis virescens & cap & & Vismia parviflora & obs & \\
\hline Schistochlamys ruficapillus & obs & & & & \\
\hline Synallaxis ruficapilla & cap & & & & \\
\hline Tachyphonus coronatus & cap/obs & cap/obs & & & \\
\hline Tangara cayana & obs & cap/obs & & & \\
\hline Tangara cyanoventris & obs & obs & & & \\
\hline Tangara desmaresti & obs & obs & & & \\
\hline Tangara ornata & obs & obs & & & \\
\hline Tangara sayaca & obs & obs & & & \\
\hline Tersina viridis & obs & & & & \\
\hline Thamnophilus caerulescens & cap/obs & obs & & & \\
\hline Todirostrum poliocephalum & obs & obs & & & \\
\hline Tolmomyias sulphurescens & & obs & & & \\
\hline Trichothraupis melanops & cap/obs & cap/obs & & & \\
\hline Turdus albicollis & cap/obs & obs & & & \\
\hline Turdus amaurochalinus & cap & obs & & & \\
\hline Turdus leucomelas & cap & & & & \\
\hline Turdus rufiventris & cap/obs & obs & & & \\
\hline Zonotrichia capensis & obs & cap & & & \\
\hline
\end{tabular}


pling, 92 interactions were recorded in native fragments among 36 bird species and 14 plants (Fig. 2A); while in eucalyptus fragments, 70 interactions among 32 birds and 11 plants were registered (Fig. 2B). Statistically, there was no differences in the number of interactions between the two types of habitats for the fecal analysis ( $W=4.0$, P-value $=0.99)$ or for the focal observations ( $W=3.5$, P-value $=0.83$ ) (Fig. 3). Almost all bird species were recorded in both types of habitats, with some exceptions such as Phibalura flavirostris Vieillot, 1816 (Cotingidae) and Dacnis cayana Sundevall, 1836 (Thraupidae), and the plant species Vismia parviflora Cham. \& Schltdl (Hypericaceae) which were found only in the native forest; and Phaeomyias murina (Spix, 1825, Tyrannidae) and Miconia valtheri Naudin (Melastomataceae) that were recorded only in the eucalyptus plantation.

Using the data obtained via fecal analysis, the highest degree of connection values in the native forest were
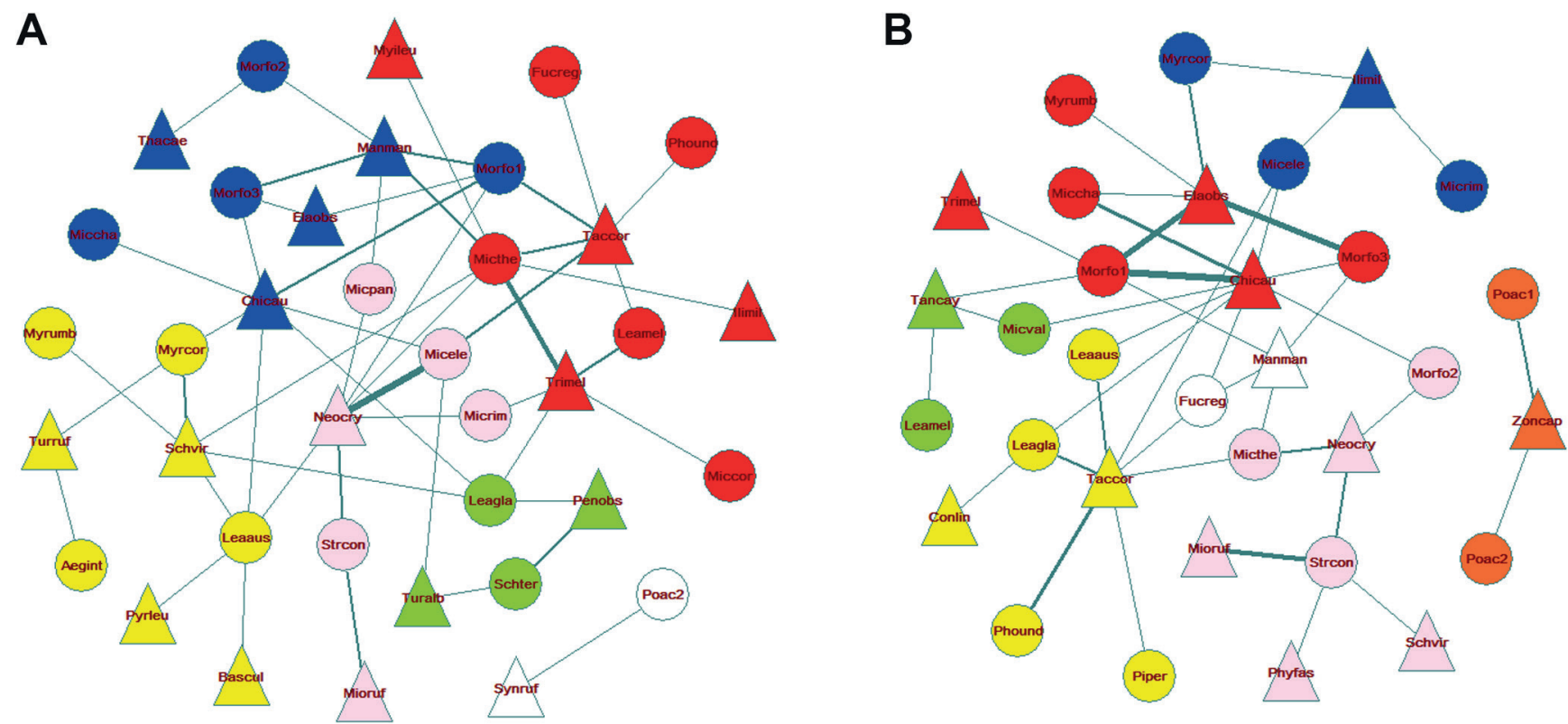

Figure 1. Interaction networks between frugivorous birds and zoochoric plants, according to the fecal samples of birds in the understory of the two sampled habitats. The circles represent the plant species, and the triangles are representing the species of birds. The acronyms in the center of the figures are the scientific names of the species (Supplementary material 1). The thickness of the links (lines) is related to the connectivity between each species (the thicker the line, the more records this interaction had). Each color represents a cluster of species that are more connected within each other than with species from other clusters due to its modularity (Q). (a): F fragments of native forest; (b): Fragments of eucalyptus plantation.
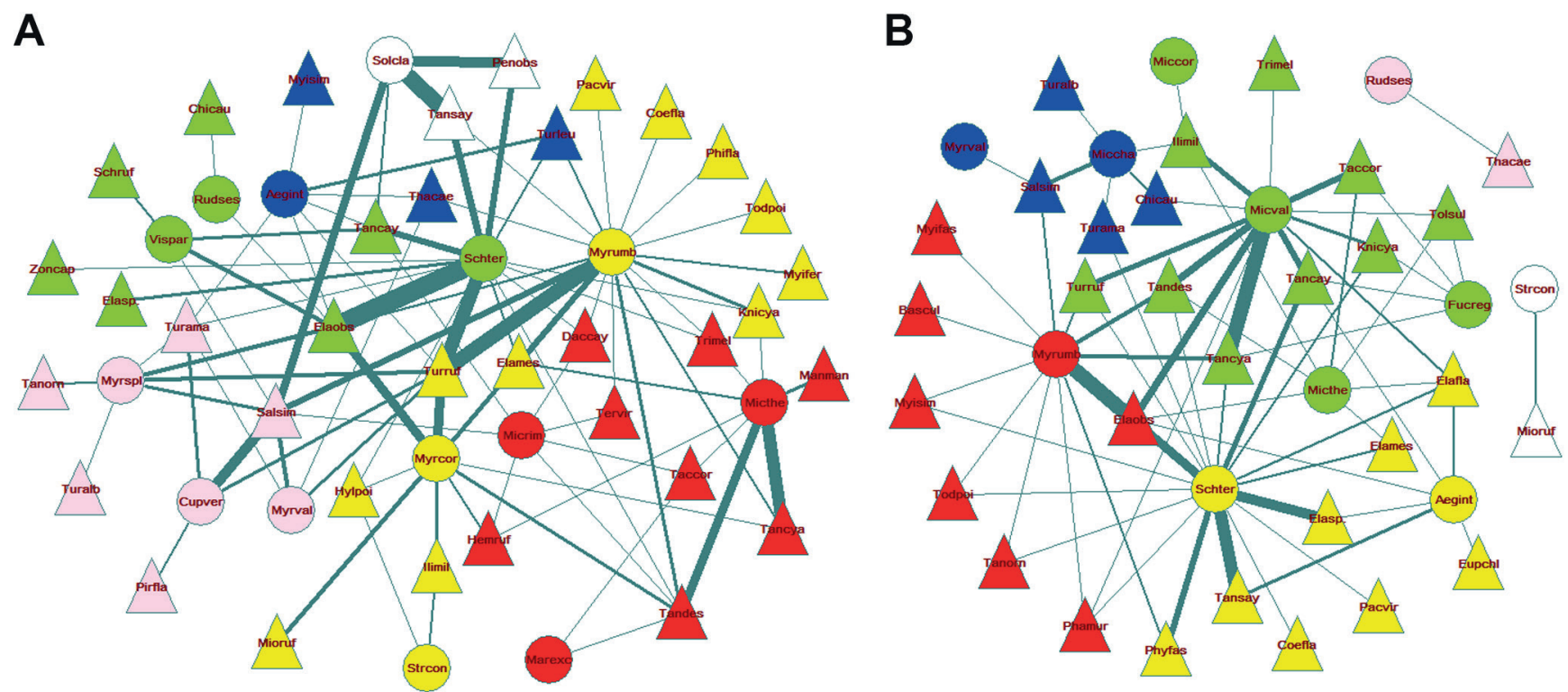

Figure 2. Interaction networks between frugivorous birds and zoochoric plants, according to the focal observations of birds in both sampled habitats. The circles represent the plant species, and the species of birds are represented by triangles. The acronyms in the center of the figures are the scientific names of the species (Supplementary material 1). The thickness of the links (lines) is related to the connectivity between each species (the thicker the line, the more records this interaction had). Each color represents a cluster of species that are more connected within each other than with between species from other clusters due to its modularity (Q). (a): Fragments of native forest; (b): Fragments of eucalyptus plantation. 
A

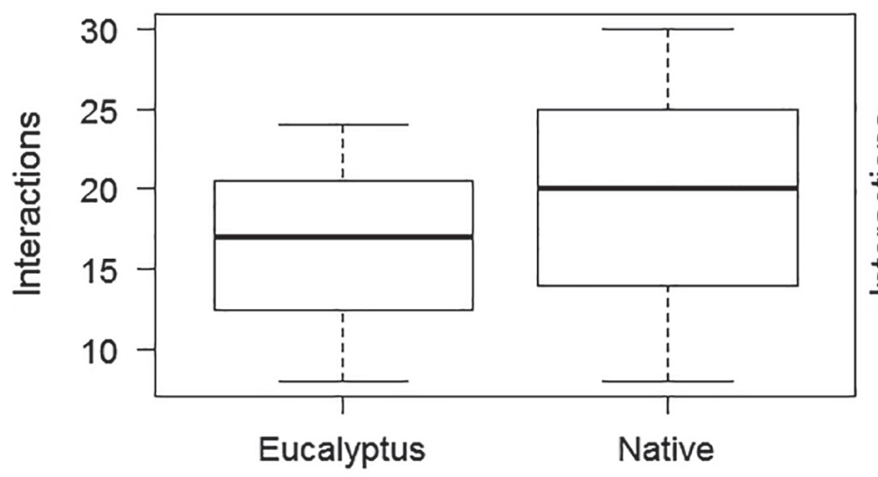

B

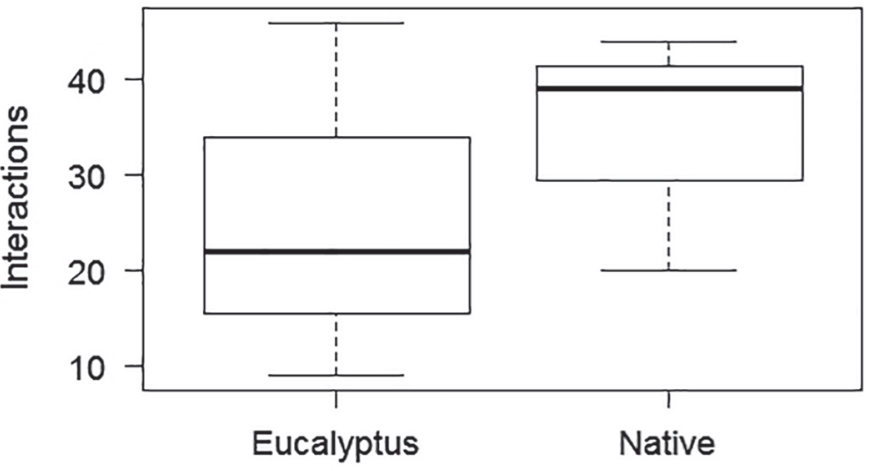

Figure 3. Comparison of the number of interactions between frugivorous birds and plants between native forest and eucalyptus plantation in the PEIT. (a): Fecal samples interactions (P-value $=0.83, \mathrm{~W}=3.5)$; $(\mathrm{b})$ : Focal observation interactions ( $P$-value $=0.99, \mathrm{~W}=4.0$ ).

observed in the interaction between Neopelma chrysolophum Pinto, 1944 (Pipridae) and Miconia elegans Cogn. (Melastomataceae). In the eucalyptus plantation, the highest degree of connection values was observed for the interaction between Chiroxiphia caudata (Shaw \& Nodder, 1793; Pipridae) and the plant Morphospecies 1. Likewise, the degree of centrality showed that the bird N. chrysolophum and the plant Miconia theaezans Bonpl. were the pair of species with the highest number of interactions in the native forest network. In the eucalyptus plantation, the bird species $C$. caudata and the plant Morphospecies1, presented the highest degree of centrality values (Supplementary material 2).

In relation to the closeness centrality in both habitats, the bird species $C$. caudata and the plant $M$. theaezans were the ones that showed the highest proximity. The betweenness centrality metric showed that bird species N. chrysolophum and C. caudata presented the highest values in both habitats. The Dispersion Importance Index (DII) indicated N. chrysolophum and Trichothraupis melanops (Vieillot, 1818; Thraupidae) as the most important seed disperser bird species in the studied native forest; while in the eucalyptus plantation, C. caudata and Tachyphonus coronatus (Vieilott, 1822; Thraupidae) were the most important seed dispersers. Conversely, the Index of importance for plants (IVIP) indicated $M$. theaezans and Leandra australis Cham. (Melastomataceae) as the most important plants in native forest, while Struthanthus concinnus Mart. (Loranthaceae) and Morphospecies 1 were the most important plants in eucalyptus plantation (Supplementary material 2).

The network connectivity in the native forest obtained through the focal observations indicated the interaction between the tree Schinus terebinthifolius Raddi (Anacardiaceae) with the bird Elaenia obscura (d'Orbigny \& Lafresnaye, 1837; Tyrannidae) as the one with the largest number of records. In the eucalyptus plantation, the greatest connectivity was observed for $M$. valtheri and Tangara cyanoventris (Vieillot, 1819; Thraupidae). The metrics of degree, closeness and betweenness centrality, in both habitats indicates that plants Myrsine umbellate Mart. (Primulaceae), S. terebinthifolius, and the bird E. ob-
Table 2. Network metrics comparisons of mutualistic bird-plant interactions between native forest and eucalyptus plantation within the PEIT with the Man-Whitney Test (W) between the three applied methodologies (all of them P-value $>0.05$ ).

\begin{tabular}{ccc}
\hline Metrics & Focal observations & Mist nets \\
\hline W / P - Value for C & $2924.5 / 0.280$ & $1066 / 0.684$ \\
W / P - Value for GC & $918 / 0.477$ & $585.5 / 0.940$ \\
W / P - Value for CC & $845 / 0.198$ & $477 / 0.168$ \\
W / P - Value for BC & $948.5 / 0.648$ & $608 / 0.848$ \\
W / P - Value for IVID & - & $154 / 0.068$ \\
W / P - Value for IVIP & - & $177 / 0.725$ \\
\hline
\end{tabular}

scura as the species with the highest number of links and importance for the network (Supplementary material 2). None of the network metrics showed significant statistical differences between native forest and eucalyptus plantations (Table 2). Also, according to the Sorensen Similarity Index, the frugivorous bird communities of both habitats presented a similarity of 0.71 , while the zoochoric plant communities of both habitats presented a similarity of 0.72 , indicating a high similarity (up to $70 \%$ ) in the composition of species which play a role in seed dispersion in both habitats.

Finally, results for the modularity generated six groups of birds and plants more related to each other in both habitats, and these results were highly identical, with the values found from the mist nets (native forest: $Q=0.49$, eucalyptus plantation: $Q=0.52$ ) and focal observations (native forest: $\mathrm{Q}=0.42$, eucalyptus plantation: $\mathrm{Q}=0.39$ ), with an average of $\mathrm{Q}=0.455$ in the two habitats.

\section{DISCUSSION}

The richness of seed dispersing birds in the eucalyptus plantation and in native forest were similar. The interaction networks were remarkably similar in both habitats, partially corroborating the initial hypothesis. These similarities between the native forest and the eucalyptus plantation found in our study could be caused by environmental characteristics of the eucalyptus plan- 
tation; the area have not been disturbed by human extractive actions for 30 years, it remains close to the native forest fragments, and exhibit a well-developed understory. Similar results were found by Stallings (1991) and Machado \& Lamas (1996), who observed that almost half of the species of mammals and birds found in the fragments of native forest were also found in eucalyptus plantations with well-developed understory; in contrast to the species found in eucalyptus plantations without understory. The understory can provide important habitat resources for wildlife species, thus improving the conservation value of eucalyptus plantations: Additionally, decreasing the use of herbicides during eucalyptus growth would allow the development of the understory and the maintenance of a greater biodiversity (Brockerhoff et al., 2008; Pereira et al., 2015). However, monocultures of introduced species, including those with a well-developed understory, certainly do not support all the diversity that would be found in a native forest (Brockerhoff et al., 2013). Therefore, they must be avoided, always giving preference to the maintenance of native forests.

The results of the network metrics in the present study were moderately higher, at least for the degree of centrality and centrality by intermediate, when compared to those found by Mello et al. (2015), who evaluated the interaction networks of bird frugivory across the Neotropics, indicating that the patterns vary enormously between the interaction networks depending on the location. On the other hand, according to Vidal et al. (2014), the number of interactions between species in mutualistic networks is strongly associated with each species contribution to modularity, which would explain why the result of the Louvain modularity (Q) in this study was notoriously similar between the two types of habitats. Silva et al. (2002) also found a similarity of $70 \%$ of frugivorous birds between a fragment of non-protected Atlantic Forest and a conserved one, inside the Intervales state park in Brazil, which could indicate the efficiency of frugivory in impacted forests within reserves.

The study of Vidal et al. (2014) registered 59 species of frugivorous birds interacting with 42 species of zoochoric plants in a well-preserved area with 120,000 ha of continuous Atlantic Forest in the south of São Paulo State. Athie \& Dias (2012) registered 38 species of birds interacting with 22 plants in fragments of 5 ha of reforested Atlantic Forest. Sarmento et al. (2014) registered 10 species of birds interacting with 39 species of plants in Atlantic Forest fragments surrounded by sugar cane plantations. These studies showed the influences of anthropogenic impacts on the interaction networks of frugivore birds and plants, with the human actions (mainly deforestation) decreasing the richness of birds, plants, and their interactions, with important changes in the composition of the community and its succession processes.

According to Lopes et al. (2005), in the Atlantic Forest domain, it is common to find intact seeds, mainly from the Melatomataceae family, in the stomach contents of the frugivorous birds of the families Thraupidae, Turdidae, and Pipridae. León (2010) also found that several species of the Thraupidae, Pipridae, and Tyrannidae families presented higher IVID values in the forests of Mexico, being the main seed dispersers. Among these families, Thraupidae is considered by Schleuning et al. (2014) as the most important group of seed dispersers in frugivory networks. In the present study, birds of the families Thraupidae, Pipridae, and Tyrannidae were the main seed dispersers in both native forest and eucalyptus plantation.

Fadini \& De Marco (2004), Lopes et al. (2005) and Athie \& Dias (2012) pointed out some of the same species found on the present study, such as C. caudata, Tangara sayaca (Linnaeus, 1766), T. coronatus and Turdus rufiventris Vieillot, 1818, as being fundamental to the interaction network of potential seed dispersers in the Atlantic Forest of the southeastern Brazil. These species are considered tolerant to the presence of exotic monocultural species, for having a generalist diet and a wide distribution, being equally registered in preserved native vegetation and in eucalyptus plantations along the Atlantic Forest domain (Machado \& Lamas, 1996; Manhaes et al., 2010). In other domains, such as in the Cerrado (savannah-like vegetation), bird T. sayaca also showed the highest interaction values (Purificação et al., 2014), while in Restinga (sandbank vegetation) in southern Brazil T. rufiventris was one of the most important bird species (Scherer et al., 2007), showing that some of these species are important seed dispersers also in other vegetation types.

According to Athie \& Dias (2012), S. terebinthifolius is one of the most important plant species in a frugivory network in the Atlantic Forest and have also been recommended for restoration processes due to its rapid growth and its importance as a resource for the avifauna (Avila et al., 2010) and entomofauna (Somavilla et al., 2010; Sühs et al., 2009). Manhaes et al. (2010) and Vidal et al. (2014) found many species of the genus Miconia, including $M$. theaezans, as important for the diet of birds and possibly for mutualistic networks, corroborating Snow (1981), who indicates the Melastomataceae family as the one with the largest number of species that offer food for seed dispersing frugivores in Neotropical forests, results in accordance with the findings of the present study. León (2010) found that several species of the genus Ficus (Moraceae) have high index of importance of plants values, being important for seed dispersion. However, plants of this genus were uncommon in the PEIT areas (Messias et al., 2017), not being recorded in the interactions observed in the present study.

Most of the species of birds and plants were recorded in both habitats, and they are common in the Atlantic Forest of southeastern Brazil, being not considered sensitive to anthropogenic impacts and do not presenting habitat restrictions in the region (Snow, 2004; Messias et al., 2017). The exceptions were the Swallow-Tailed Cotinga ( $P$. flavirostris), registered only in the native forest and considered near threatened by Birdlife International (2016), and M. valtheri, a species of zoochoric tree registered for the first time in the PEIT (OUPR 34035), only in the eucalyptus plantation. This is a pioneer species like many others of the Miconia genus (Manhaes et al., 2010; Vidal et al., 2014). 


\section{CONCLUSION}

Species richness and the complexity of interactions between frugivorous birds and zoochoric plants were similar in both, the abandoned eucalyptus plantation and native forests in the present study. This indicates a possibly same potential for seed dispersal in both studied forests, also suggesting the same potential for regeneration. Therefore, in the PEIT, the presence of the abandoned eucalyptus plantation is not being considered an obstacle to the regeneration of the Atlantic Forest, thanks to the fact that the natural succession process is being allowed in the understory. It is important to mention that adding more sampling points in different areas of the two habitats in future studies would increase the representativeness of the mutualistic interaction networks and the power of the analysis, resulting in more robust and refined information.

\section{ACKNOWLEDGMENTS}

Authors would like to thank UFOP and CAPES for the logistic support during the development of this study the licenses granted by IEF (093-2018), SISBIO (63431-2) and CEUA (4425170918), and to the Herbário José Badini (OUPR) for the identification of the plant samples. CDVB thanks the scholarship received from OEA/GCUB. The authors would also like to thank all the PEIT staff who helped directly and indirectly with this study.

\section{AUTHORS' CONTRIBUTIONS}

CVB: Conceptualization, Methodology, Data curation, Formal analysis, Writing - original draft, Visualization, Investigation. Writing - review \& editing. MFOP: Conceptualization, Methodology, Writing - original draft, Visualization, Investigation. Writing - review \& editing. CSA: Supervision, Writing - review \& editing. All the authors actively participated in the discussion of the results, they reviewed and approved the final version of the paper.

\section{REFERENCES}

Altieri, M.A. 2009. The ecological impacts of large-scale agrofuel monoculture production systems in the Americas. Bulletin of Science, Technology \& Society, 29: 236-244. D0I

Amico, G. \& Aizen, M. 2005. Seed dispersal by birds in a temperate forest of southern South America: Who disperses whom? Ecología Austral, 15: 89-100.

Andrade, M. 1998. 0 Parque Estadual do Itacolomi e suas aves. Uiraçu, 2(2): 4.

Athie, S. \& Dias, M. 2012. Frugivory by birds in a mosaico of seasonal semideciduous forest and mixed reforestation in Rio Claro, São Paulo, Brazil. Acta Botanica Brasilica, 26(1): 84-93.

Avila, G.; Gomes, A.; Canary, A. \& Bugoni, L. 2010. The role of avian frugivores on germination and potential seed dispersal of the Brazilian pepper Schinus terebinthifolius. Biota Neotropica, 10(3): 45-51. http://www. biotaneotropica.org.br/v10n3/en/abstract?article+bn00910032010.
Barlow, J.; Gardner, T.; Araujo, I.; Avila-Pires, T.; Bonaldo, A.; Costa, J.; Esposito, M.; Ferreira, L.; Hawes, J.; Hernandez, M.; Leite, R.; Lo-Man-Hung, N.; Malcolm, J.; Martins, M.; Mestre, L.; Nunes-Gutjahr, A.; Overal, W.; Parry, L.; Peters, S.; Ribeiro-Jr., M.; Da Silva Motta, C. \& Da Silva, M. 2007. Quantifying the biodiversity value of tropical primary, secondary, and plantation forests. Proceedings of the National Academy of Sciences, U.S.A., 104(47): 18555-18560.

Bascompte, J. \& Jordano, J. 2007. Plant-Animal mutualistic networks: The architecture of biodiversity. Annual Review of Ecology, Evolution, and Systematics, 38: 567-593.

Bascompte, J. \& Jordano, P. 2014. Mutualistic networks. Princeton, Princeton University Press.

Batagelj, V. \& Mrvar, A. 1998. Pajek - a program for large network analysis. Available: http://vlado.fmf.unilj.si/pub/networks/pajek. Access: 15/11/2019.

Bayle, G.K. 2019. Eological and social impacts of eucalyptus tree plantation on the environment. Journal of Biodiversity Conservation and Bioresource Management, 5: 93-104. DOI

Benton, T.G.; Bieg, C.; Harwatt, H.; Pudasaini, R. \& Wellesley, L. 2021. Food system impacts on biodiversity loss. London, Chatham House.

Birdlife International. 2016. Swallow-tailed Cotinga Phibalura flavirostris. Available: http://www.birdlife.org. Access: 11/03/2020.

Borsboom, A.; Wang, J.; Lees, N.; Mathieson, M. \& Hogan, L. 2002. Measurement and integration of fauna biodiversity values in Queensland agroforestry system. Canberra, Joint Venture Agroforestry Program. Rural Industries Research and Development Corporation, 2: 44.

Bremer, L. \& Farley, L. 2010. Does plantation forestry restore biodiversity or create green deserts? A synthesis of effects of land-use transitions on plant species richness. Biodiversity and Conservation, 19(14): 3893-3915.

Brockerhoff, E.; Jactel, H.; Parrotta, J. \& Ferraz, S. 2013. Role of eucalypt and other planted forests in biodiversity conservation and the provision of biodiversity-related ecosystem services. Forest Ecology and Management, 301: 43-50.

Brockerhoff, E.; Jactel, H.; Parrotta, J.; Quine, C. \& Sayer, J. 2008. Plantation forests and biodiversity: 0xymorom or opportunity? Biodiversity and Conservation, 17: 925-951.

Carnus, J.; Parrotta, J.; Brockerhoff, E.; Arbez, M.; Jactel, H.; Kremer, A.; Lamb, D.; O'hara, K. \& Walters, B. 2006. Planted forests and biodiversity. Journal of Forestry, 104(2): 65-77.

Caziani, S. 1996. Plant-seed dispersal bird interaction in a semi-arid Chaco forest. (Doctoral thesis). Facultad de ciencias exactas y naturales, Universidad de Buenos Aires. Buenos Aires, Argentina.

Ceccon, E. 2001. Un paraíso casi perdido: breve historia de la deforestación en Brasil. Ciência, México, DF, 64: 22-29.

Costa, F.; Ribeiro, M.; Bronstein, J.; Guerra, T.; Muylaert, R.; Leite, A. \& Neves, F. 2016. Few ant species play a central role linking different plant resources in a network in rupestrian grasslands. Plos One, 11(2): e0167161. DOI

Cullen, L.; Rudran, R. \& Valladares-Padua, C. 2006. Métodos de estudo em biologia da conservação e manejo da vida silvestre. 2.ed. Curitiba, UFPR.

Edwards, F.A.; Edwards, D.P.; Sloan, S. \& Hamer, K.C. 2014. Sustainable management in crop monocultures: the impact of retaining forest on oil palm yield. Plos One, 9(3): e91695. D0I

Fadini, R. \& De Marco, P. 2004. Interactions between frugivorous birds and plants in Atlantic Forest fragment in Minas Gerais. Ararajuba, 12(2): 97-103.

Fleming, T. \& Kress, W. 2011. A brief history of fruits and frugivores. Acta Oecologica, 37(6): 521-530.

Food and Agriculture Organization (FA0). 2016. The state of the world's forests: Forests and agriculture, challenges and opportunities in relation to land use. Roma, Food and Agriculture Organization of the United Nations. 
Frigieri, F.; Iwanicki, N.; Gandara, F.; Ferraz, E.; Romão, G.; Coletti, G.; Souza, V. \& Moreno, M. 2016. Guia de plântulas e sementes da Mata Atlantica do Estado de São Paulo. Piracicaba, IPEF. 99p.

Galindo, J.; Guevara, S. \& Sosa, V. 2000. Bat and bird generated seed rains at isolated tree in pastures in a tropical rain forest. Conservation Biology, 14(6): 1693-1703.

Governo do Estado de Minas Gerais, Secretaria de Estado de Meio Ambiente e Desenvolvimento Sustentável (SEMAD), Instituto Estadual de Florestas de Minas Gerais (IEF), Projeto de Proteção da Mata Atlântica em Minas Gerais (PROMATA). 2007. Management plan for the Itacolomi State Park: Chapter 1 - Park Diagnostic. Belo Horizonte.

Hernández-Ladrón de Guevara, I.; Rojas-Soto, 0.; López-Barrera, F.; PueblaOlivares, F. \& Díaz-Castelazo, C. 2012. Seed dispersal by birds in a mesophilic forest landscape in central Veracruz, México: Your role in passive restoration. Revista Chilena de Historia Natural, 85: 89-100.

Hobbs, R.; Catling, P.; Wombey, J.; Clayton, M.; Atkins, L. \& Reid, A. 2003. Faunal use of bluegum (Eucalyptus globulus) plantations in southwestern, Australia. Agroforestry Systems, 58: 195-212.

Kanowski, J.; Catterall, C. \& Wardelljohnson, G. 2005. Consequences of broadscale timber plantations for biodiversity in cleared rainforest landscapes of tropical and subtropical Australia. Forest Ecology and Management, 208(1-3): 359-372.

Kuhlmann, M. 2012. Fruits and seed of Cerrado attractive to fauna: Field guide. Editora Rede de Sementes do Cerrado.

León, E. 2010. Seed rain by birds and bats to pastures associated with a fragment of tropical dry forest (Córdoba - Colombia). (Graduation Monography). Bogotá, Pontificia Universidad Javeriana.

Lopes, L.; Fernandes, A. \& Marini, M. 2005. Diet of some Atlantic Forest birds. Ararajuba, 13(1): 95-103.

Machado, R. \& Lamas, I. 1996. Birdlife associated with eucalyptus reforestation in the municipality of Antônio Dias, Minas Gerais. Ararajuba, 4(1): 15-22.

Manhaes, M.; Loures-Ribeiro, A. \& Dias, M. 2010. Diet of understory birds in two Atlantic Forest areas of southeast Brazil. Journal of Natural History, 44(7): 469-489.

Markl, J.; Schleuning, M.; Forget, P.; Jordano, P.; Lambert, J.; Traveset, A.; Wright, S. \& Bohning-Gaese, K. 2012. Meta-Analysis of the effects of human disturbance on seed dispersal by animals. Conservation Biology, 26(6): 1072-1081.

Marsden, S.; Whiffin, M. \& Galetti, M. 2001. Bird diversity and abundance in forest fragments and Eucalyptus plantations around an Atlantic Forest reserve, Brazil. Biodiversity and Conservation, 10(5): 737-751.

Mello, M.; Muylaert, R.; Pinheiro, R. \& Felix, G. 2016. Guide to ecological network analysis. Available: https://www.researchgate.net/profile/ Marco Mello/publication/307940803 Guia para analise de redes ecologicas/links/5ceb0c31458515712ec5f040/Guia-para-analise-deredes-ecologicas.pdf. Access: 15/02/2020.

Mello, M.; Rodrigues, F.; Costa, L.; Kissling, W.; Sekercioglu, Ç.; Marquitti, F. \& Kalko, E. 2015. Keystone species in seed dispersal networks are mainly determined by dietary specialization. Oikos, 124(8): 1031-1039.

Messias, M.; Sousa, H.; Scalon, V.; Roschel, M.; Candido, E. \& Fujaco, M. 2017. Phanerogamic flora and vegetation of Itacolomi State Park, Minas Gerais, Brazil. Biota Neotropica, 17(1): e20160236. D0I

Myers, N.; Mittermeier, R.A.; Fonseca, G.A.B. \& Kent, J. 2000. Biodiversity hotspots for conservation priorities. Nature, 403(6772): 853-858. D0I

Pereira, H.; Silvéiro, M.; Schetini, C. \& Ribon, R. 2015. Wealth and density of birds that nest in cavities in abandoned eucalyptus plantations. Papéis Avulsos de Zoologia, 55(5): 81-90.
Pizo, M. \& Galetti, M. 2010. Methods and perspectives for the study of frugivory and seed dispersal by birds. In: Von Matter, S.; Straube, F.; Accordi, I.; Piacentini, V. \& Candido, J. (Coord.). Ornithology and conservation: Applied science, research techniques and surveys. Rio de Janeiro, Technical Books Editora. p. 491-504.

Purificação, K.; Pascotto, M.; Pedroni, F.; Pereira, J. \& Lima, N. 2014. Interactions between frugivorous birds and plants in savannah and forest formations of the Cerrado. Biota Neotropica, 14(4). D0I

R Development Team. 2018. R: A language and environment for statistical computing. $R$ foundation for statistical computing. Viena.

Rabinovich, J. 1981. Ecologia de poblaciones animales. Editora Continental. México.

Rezende, C.L.; Scarano, F.R.; Assad, E.D.; Joly, C.A.; Metzger, J.P.; Strassburg, B.B.N.; Tabarelli, M.; Fonseca, G.A. \& Mittermeier, R.A. 2018. From hotspot to hopespot: An opportunity for the Brazilian Atlantic Forest. Perspectives in Ecology and Conservation, 16(4): 208-214. D0I

Sarmento, R.; Alves-Costa, C.; Ayub, A. \& Mello, M. 2014. Partitioning of seed dispersal services between birds and bats in a fragment of the Brazilian Atlantic Forest. Zoologia, Curitiba, 31(3): 245-255.

Scherer, A.; Maraschin-Silva, F. \& Baptista, M. 2007. Patterns of mutualistic interactions between tree species and frugivorous birds in a Restinga community in the state park of Itapuã, RS, Brazil. Acta Botanica Brasilica, 21(1): 203-212.

Schleuning, M.; Ingmann, L.; Strauss, R.; Fritz, S.; Dalsgaard, B.; Dehling, D. \& Böhning-Gaese, K. 2014. Ecological, historical and evolutionary determinants of modularity in weighted seed-dispersal networks. Ecology Letters, 17(4): 454-463.

Sigrist, T. 2014. Avis Brasilis field guide: Brazilian birdlife. São Paulo, Avis Brasilis.

Silva, W.; De Marco, P.; Hasui, E. \& Gomes, V. 2002. Patterns of fruit-frugivore interactions in two Atlantic Forest bird communities of south-eastern Brazil: Implications for conservation. In: Levey, D.; Silva, W. \& Galetti, M. Seed dispersal and frugivory: Ecology, evolution and conservation. Oxon, UK, CABI publishing. p. 423-436.

Snow, D. 1981. Tropical frugivorous birds and their food plants: a world survey. Biotropica, 13: 1-14.

Snow, D. 2004. Family Cotingidae (Cotingas). In: Del Hoyo J.; Elliot A. \& Christie D. (Eds.). Handbook of the birds of the world: Cotingas to Pipit and Wagtails. London, Lynx Editions. v. 9, p. 32-109.

Somavilla, A.; Sühs, R.B. \& Köhler, A. 2010. Entomofauna associated to the floration of Schinus terebinthifolius Raddi (Anacardiaceae) in the Rio Grande do Sul state, Brazil. Bioscience Journal, 26(6): 956-965.

Stallings, J. 1991. The importance of understory on wildlife in Brazilian eucalypt plantation. Revista Brasileira de Zoologia, 7(3): 267-276.

Sühs, R.B.; Somavilla, A.; Köhler, A. \& Putzke, J. 2009. Pollen vector wasps (Hymenoptera, Vespidae) of Schinus terebinthifolius Raddi (Anacardiaceae), Santa Cruz do Sul, RS, Brazil. Brazilian Journal of Biosciences, Porto Alegre, 7(2): 138-143.

Tafuri, A. 2008. Environmental evaluation of Itacolomi State Park, Ouro Preto, Minas Gerais. (Masters dissertation). Belo Horizonte, Universidade Federal de Minas Gerais.

Valduga, M.; Zenni, R. \& Vitule, J. 2016. Ecological impacts of non-native tree species plantations are broad and heterogeneous: A review of Brazilian research. Anais da Academia Brasileira de Ciências, 88(3): 1675-1688.

Vidal, M.; Hasui, E.; Pizo, M.; Tamashiro, J.; Silva, W. \& Guimarães, P. 2014. Frugivores at higher risk of extinction are the key elements of a mutualistic network. Ecology, 95(12): 3440-3447. 
SUPPLEMENTARY MATERIAL 1

\begin{tabular}{|c|c|c|c|}
\hline Plants & Acronym & Birds & Acronym \\
\hline Aegiphila integrifolia & Aegint & Basileuterus culicivorus & Bascul \\
\hline Cupania vernalis & Cupver & Chiroxiphia caudata & Chicau \\
\hline Fuchsia regia & Fucreg & Coereba flaveola & Coefla \\
\hline Leandra australis & Leaaus & Conopophaga lineata & Conlin \\
\hline Leandra glabrata & Leagla & Dacnis cayana & Daccay \\
\hline Leandra melastomoides & Leamel & Elaenia flavogaster & Elafla \\
\hline Marlieria excoriata & Marexc & Elaenia mesoleuca & Elames \\
\hline Miconia chartacea & Miccha & Elaenia obscura & Elaobs \\
\hline Miconia corallina & Miccor & Elaenia sp. & Elasp \\
\hline Miconia elegans & Micele & Euphonia chlorotica & Eupchl \\
\hline Miconia paniculata & Micpan & Hemithraupis ruficapilla & Hemruf \\
\hline Miconia rimalis & Micrim & Hylophilus poicilotis & Hylpoi \\
\hline Miconia theaezans & Micthe & Ilicura militaris & Ilimil \\
\hline Miconia valtheri & Micval & Knipolegus cyanirostris & Knicya \\
\hline Morphospecie 1 & Morfo1 & Manacus manacus & Manman \\
\hline Morphospecie 2 & Morf02 & Mionectes rufiventris & Mioruf \\
\hline Morphospecie 3 & Morf03 & Myiarchus ferox & Myifer \\
\hline Myrcia splendens & Myrspl & Myiophobus fasciatus & Myifas \\
\hline Myrcia vauthieriana & Myrval & Myiothlypis leucoblephara & Myileu \\
\hline Myrsine coriacea & Myrcor & Myiozetetes similis & Myisim \\
\hline Myrsine umbellata & Myrumb & Neopelma chrysolophum & Neocry \\
\hline Phoradendron undulatum & Phound & Pachyramphus viridis & Pacvir \\
\hline Pipersp. & Piper & Penelope obscura & Penobs \\
\hline Poacea 1 & Poac1 & Phaeomyias murina & Phamur \\
\hline Poacea 2 & Poac2 & Phibalura flavirostris & Phifla \\
\hline Rudgea sessilis & Rudses & Phyllomyias fasciatus & Phyfas \\
\hline Schinus terebintifolios & Schter & Piranga flava & Pirfla \\
\hline Solanum cladotrichum & Solcla & Pyriglena leucoptera & Pyrleu \\
\hline Struthanthus conccinnus & Strcon & Saltator similis & Salsim \\
\hline \multirow[t]{19}{*}{ Vismia parviflora } & Vispar & Schiffornis virescens & Schvir \\
\hline & & Schistochlamys ruficapillus & Schruf \\
\hline & & Syndactila rufosupercilliata & Synruf \\
\hline & & Tachyphonus coronatus & Taccor \\
\hline & & Tangara cayana & Tancay \\
\hline & & Tangara cyanoventris & Tancya \\
\hline & & Tangara desmaresti & Tandes \\
\hline & & Tangara ornata & Tanorn \\
\hline & & Tangara sayaca & Tansay \\
\hline & & Tersina viridis & Tervir \\
\hline & & Thamnophilus caerulescens & Thacae \\
\hline & & Todirostrum poliocephalum & Todpoi \\
\hline & & Tolmomyias sulphurescens & Tolsul \\
\hline & & Trichothraupis melanops & Trimel \\
\hline & & Turdus albicollis & Turalb \\
\hline & & Turdus amaurochalinus & Turama \\
\hline & & Turdus leucomelas & Turleu \\
\hline & & Turdus rufiventris & Turruf \\
\hline & & Zonotrichia capensis & Zoncap \\
\hline
\end{tabular}




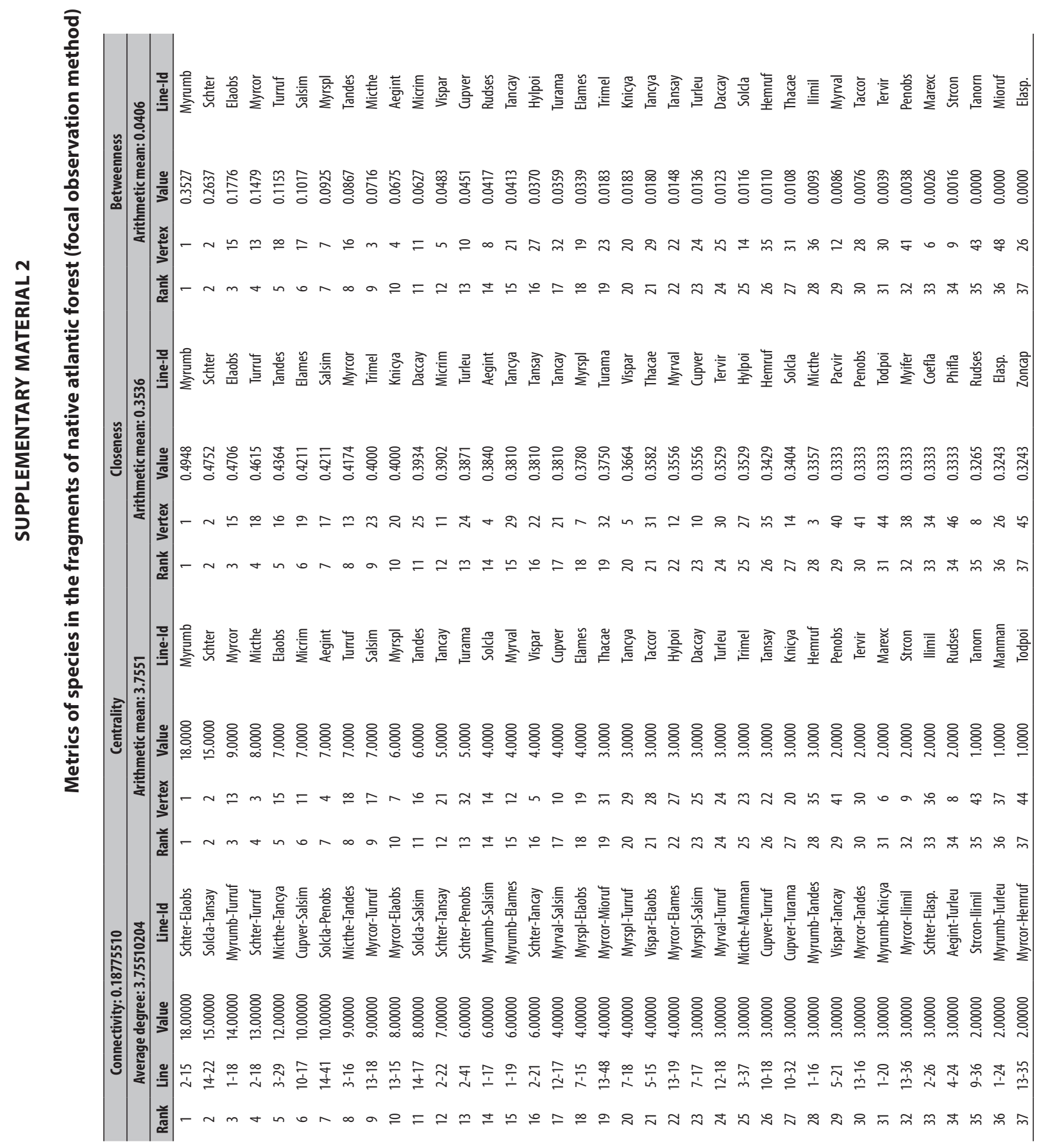




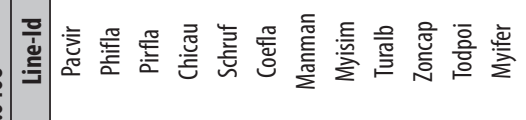

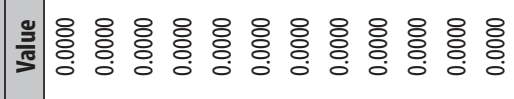

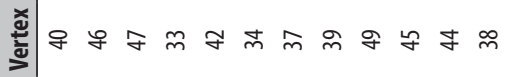

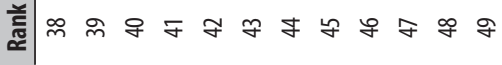

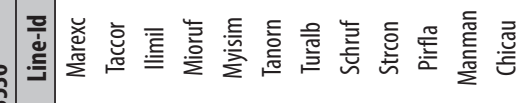

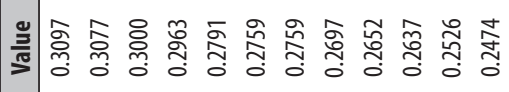

產

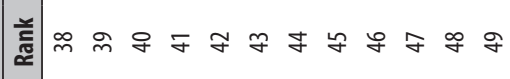

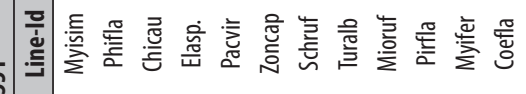

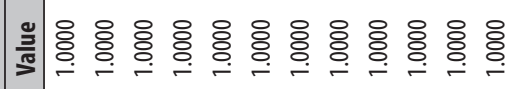

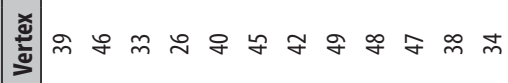

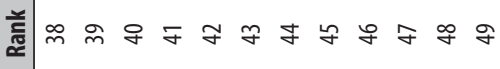

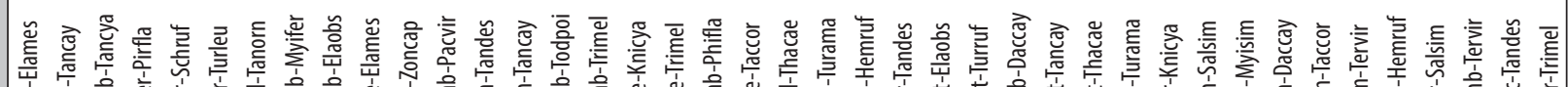

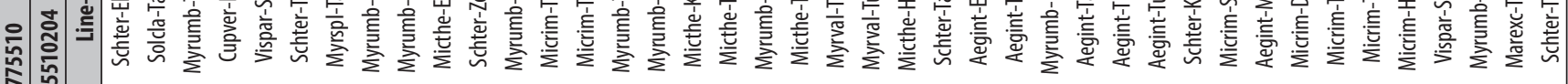

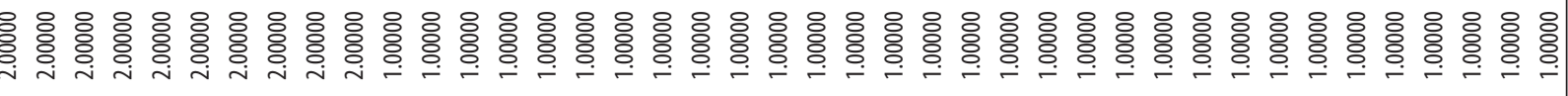

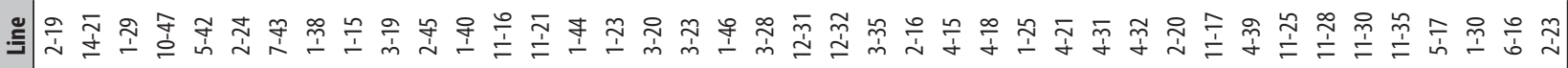

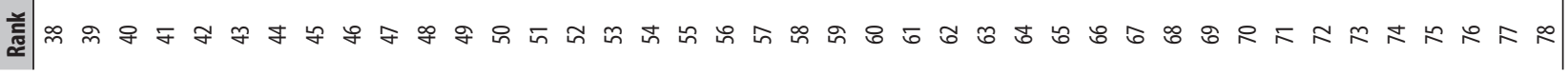



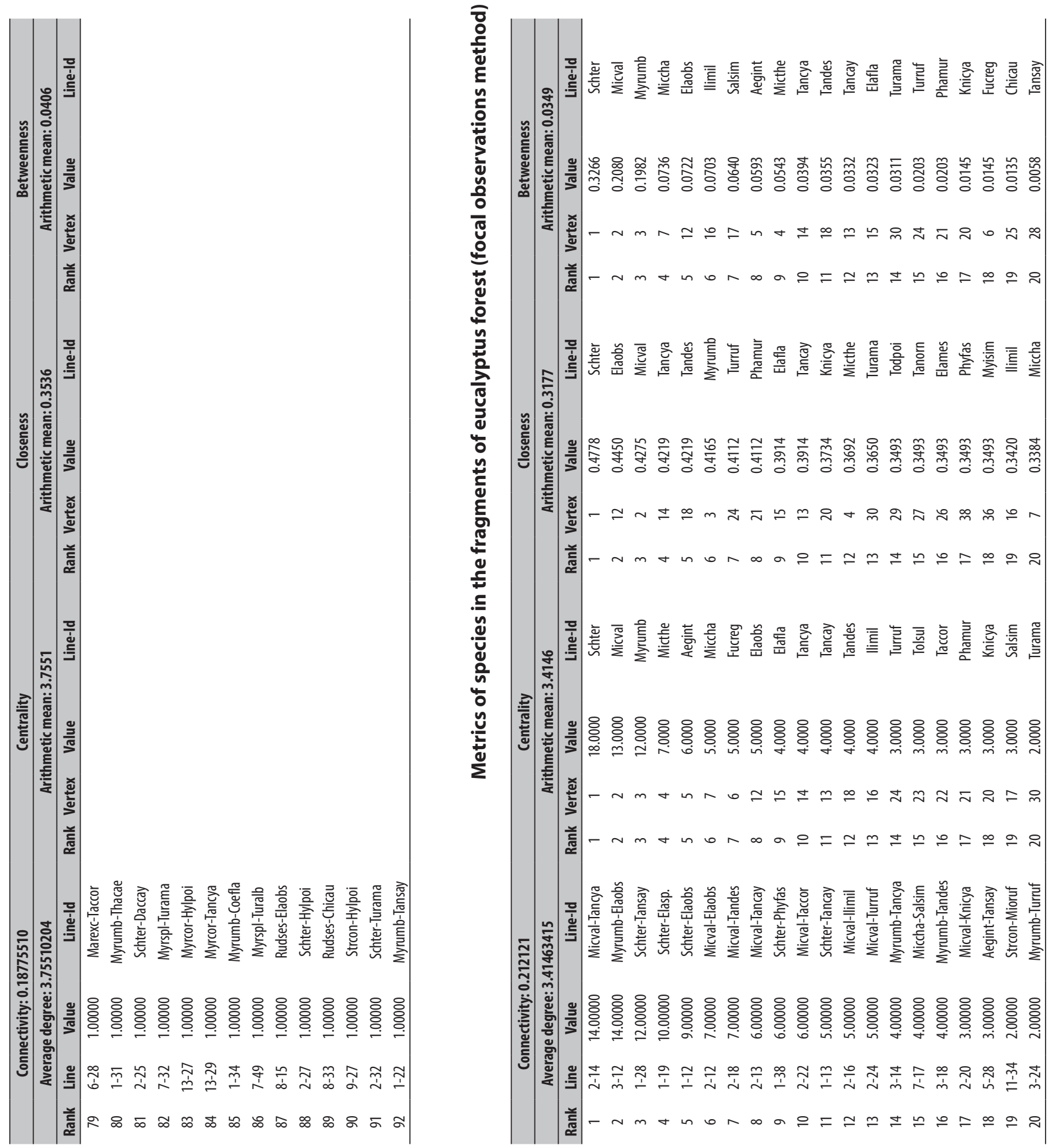


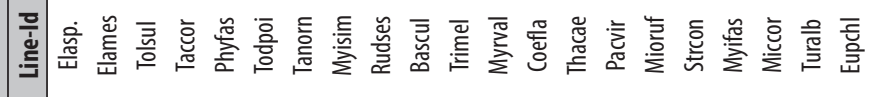

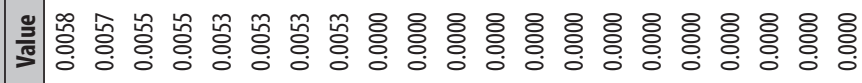

產

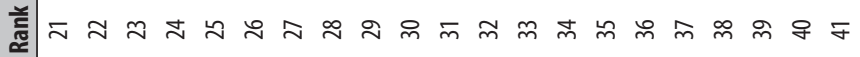

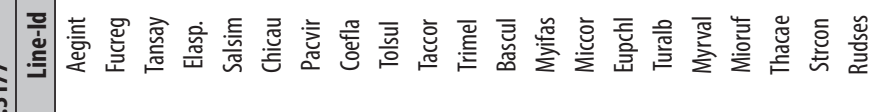

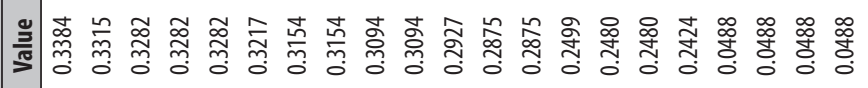

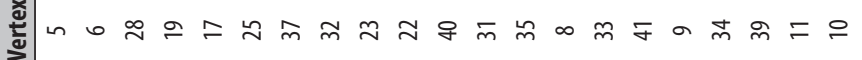

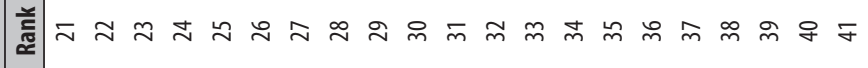

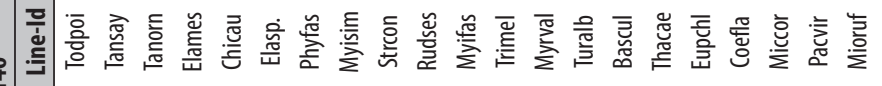

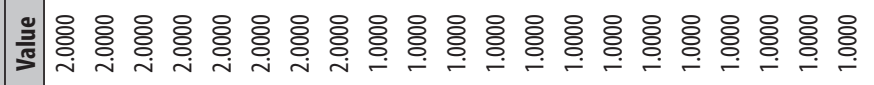

彦

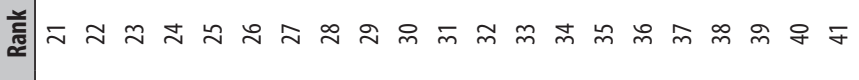

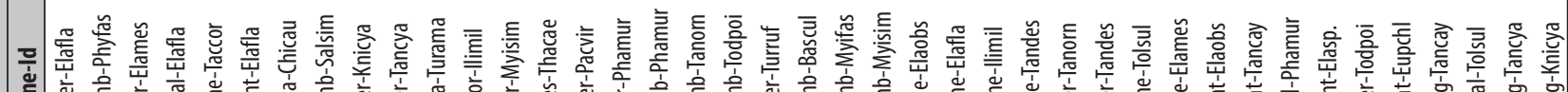

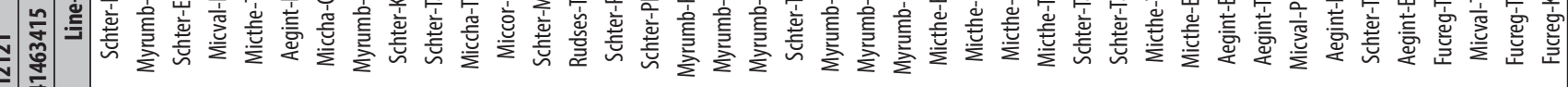




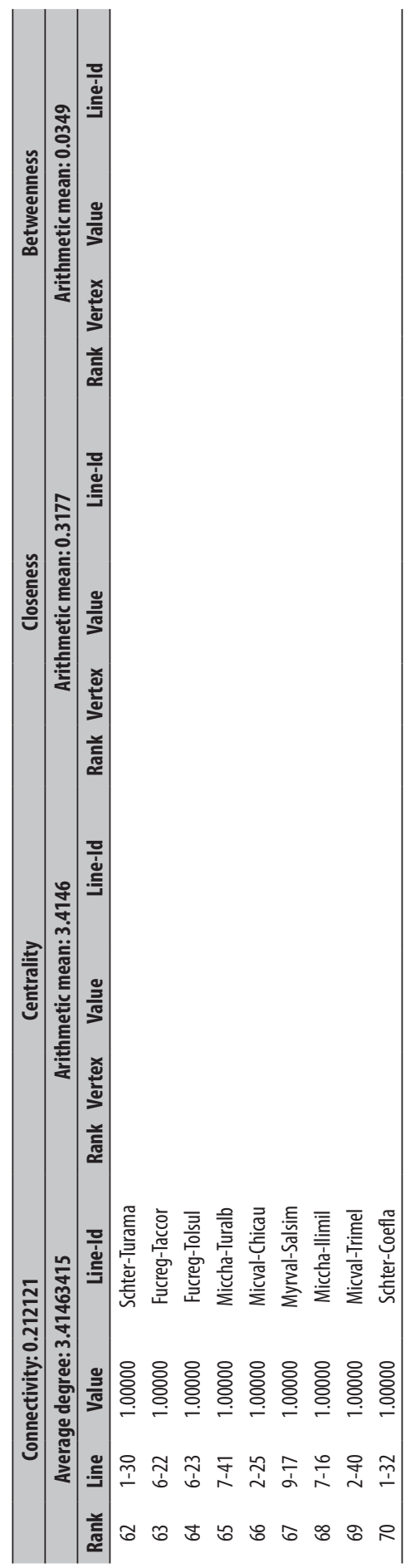

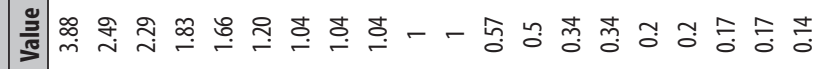

$\underline{\underline{\underline{y}}}$

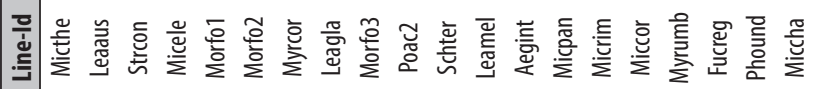

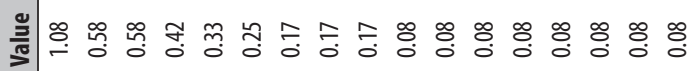

产

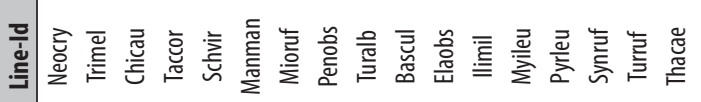

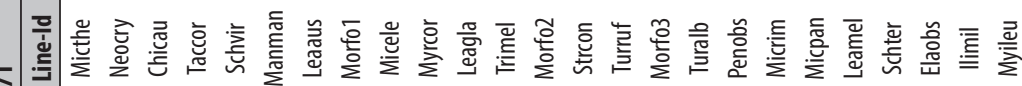

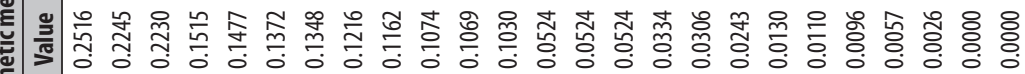
產

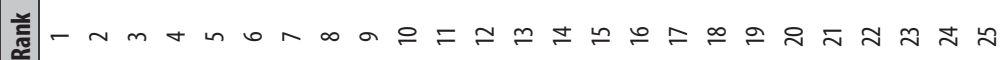

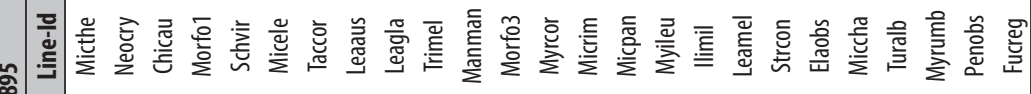

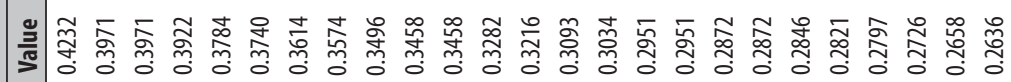

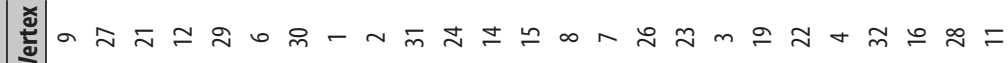

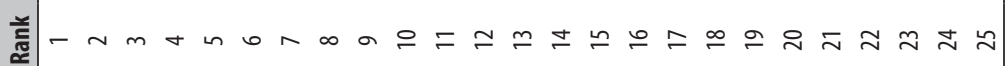

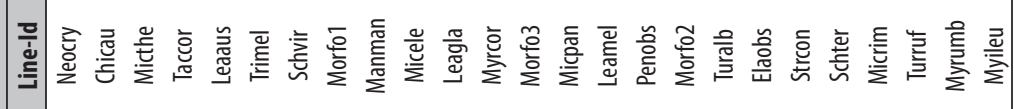

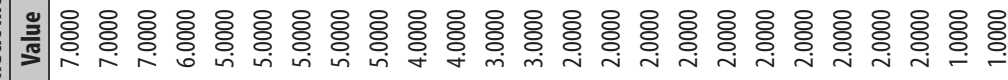

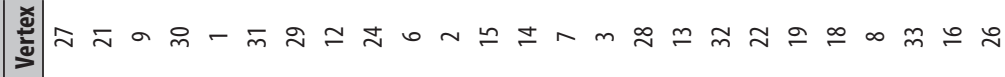

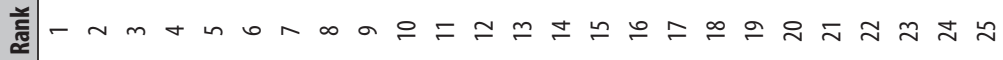

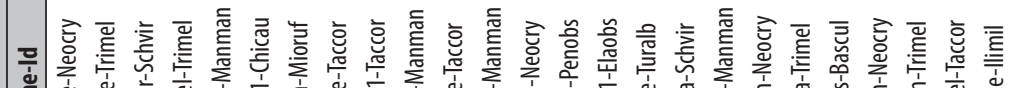

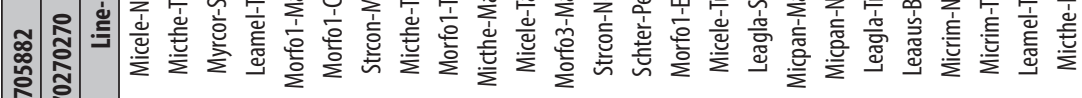



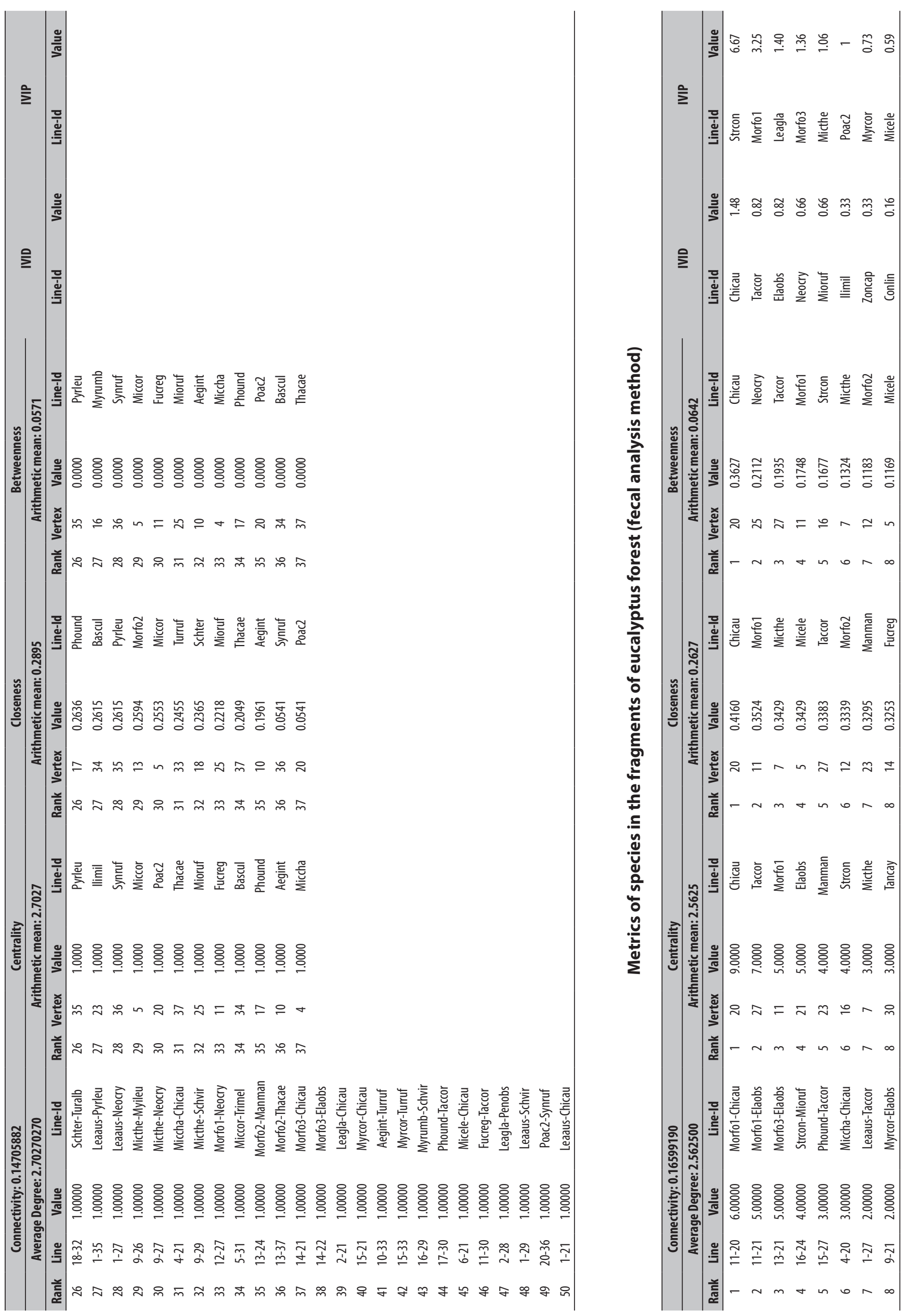


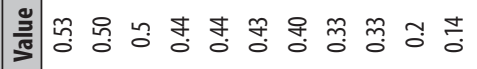

$\underline{\underline{\underline{\Sigma}}}$

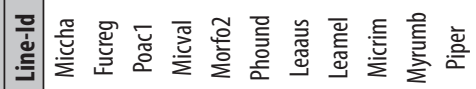

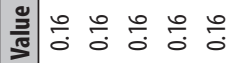

$\underline{\underline{\underline{I}}}$

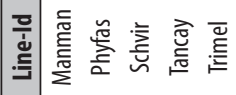

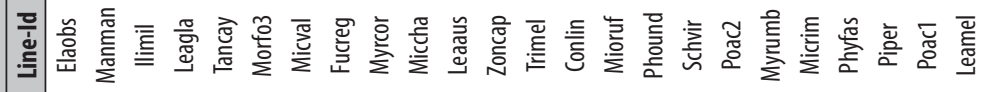

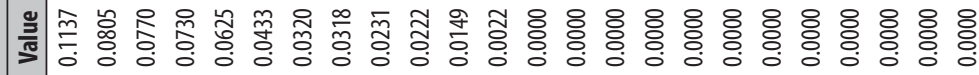

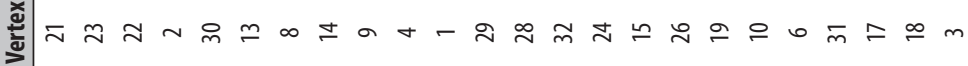

鄯

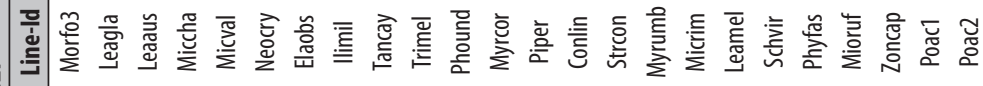

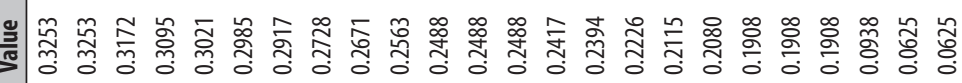

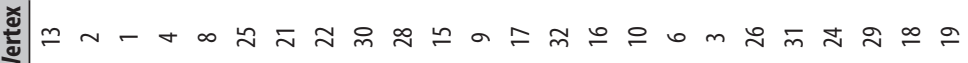

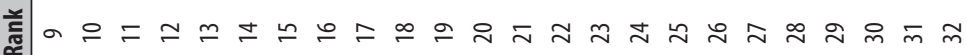

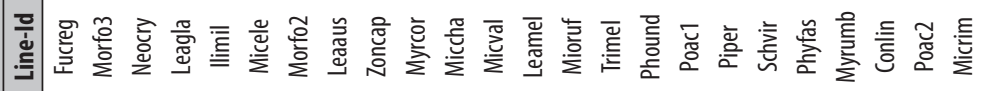

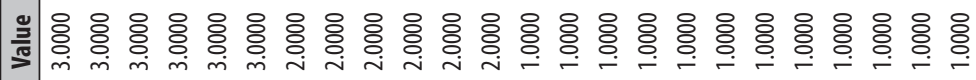

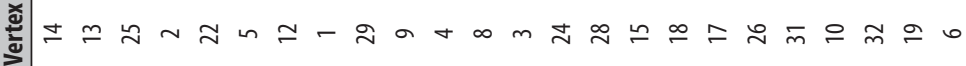

善

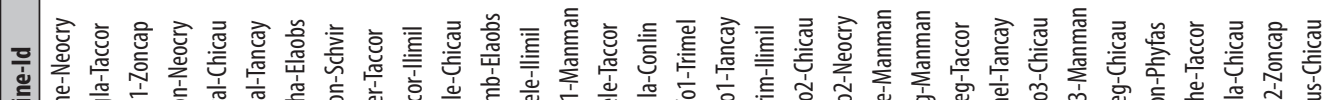

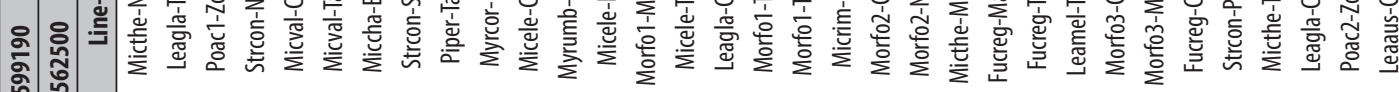

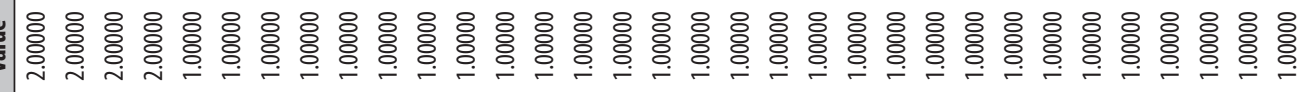

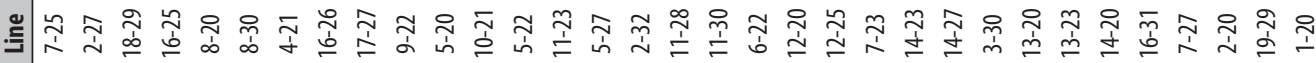

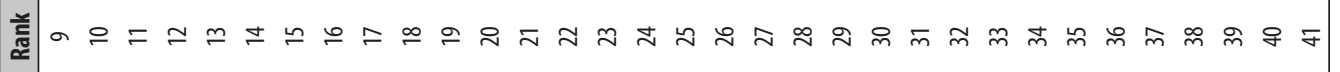

